\title{
The Perils of Outcomes-Based Education in Fostering South African Educational Transformation
}

\author{
Michèle J. Schmidt \\ Simon Fraser University, British Columbia, Canada \\ Email: mschmidt@sfu.ca
}

How to cite this paper: Schmidt, M. J. (2017). The Perils of Outcomes-Based Education in Fostering South African Educational Transformation. Open Journal of Political Science, 7, 368-379. https://doi.org/10.4236/ojps.2017.73030

Received: November 21, 2016

Accepted: July 4, 2017

Published: July 7, 2017

Copyright $\odot 2017$ by author and Scientific Research Publishing Inc. This work is licensed under the Creative Commons Attribution International License (CC BY 4.0).

http://creativecommons.org/licenses/by/4.0/

\section{(c) (i) Open Access}

\begin{abstract}
This chapter explored a South African education policy. Specifically the author examined outcomes-based learning and the implications of this borrowed curriculum in South African schools. The author focused on curriculum as a platform for discussion of the unique approach that the South African government employed to modify their adoption of democracy and transformation. Unfortunately, many scholars reluctantly concede that South Africa's ambitious policy initiatives failed to provide social justice in schools. Education is often the driving force in society: socially, economically, and politically. In particular, education can either liberate social ideologies or become a tool to reinforce stratification. With a political ideology of democracy emerging in South Africa, one would think that democratic educational structures would act to diminish race, class and gender inequalities; however, this has not been a pervasive result.
\end{abstract}

\section{Keywords}

Curriculum, Outcomes-Based Education, South Africa, Postmodern Policy Analysis

\section{Introduction}

This paper explores South African school curriculum policy as a platform to discuss the success or failure of educational policy. An examination of policies in post-apartheid South Africa shows the unique approach that the government employed to adopt democracy. Unfortunately, many scholars concede that South Africa's ambitious curriculum policies reveal numerous failings and tensions in schools (Spreen \& Vally, 2006; South African Policy Brief 2010). Organized in such a way as to introduce the policy problem, the paper also traces the history 
of education in South Africa; examines Curriculum 2005 (C2005) and OutBased Education (OBE), and discusses the implications of OBE within a South African context.

\section{Historical Perspective of Policy}

The paper employs a post modern policy approach. Such a tool provides a strategic framework with which to reconsider South African curriculum policy as a means to foster democracy, culture, and equality. Several major paradigm shifts related to policy can be traced to the 1950s. Changes do not necessarily signal a complete break from previous approaches when policy changes are introduced. Rather, change promotes a gradual refining of the tools and skills utilized in the treatment of policy (Zajda, 2002: p. 70). The 1950s and the 1960s used linear approaches to policy models. By the 1970s, a paradigm shift occurred from quantitative to qualitative research, leading to a questioning of the value-free empirical research approach in education (Coombs and Lüschen, 1976: p. 134). Further policy changes in the 1980s and 1990s occurred including the paradigm shift in the social sciences from structuralism to post-structuralism and postmodernism. Consequently, in "modern" society, value-neutral policy frameworks existed to evaluate systems and to focus on the extent to which the policy succeeded or failed to meet its objectives. Unfortunately, those who apply such policy and those upon whom the policy is implemented, are often not considered. Value-free policy processes are unable to examine the power relations of the problems that they attempt to address (Ball, 1994; Schmidt, 2008).

Such traditional policy analyses are not adequate for the analysis of outcomes-based (OBE) efforts in South Africa (Schmidt, 2008; Taylor, Rizvi, Lingard, \& Henry, 1997). Traditional policy processes are modern inventions that give privileges to process and reason. Most of these written policies reflect the government's intentions to address a problem, which was designed to achieve particular goals (Schmidt, 2008; Taylor et al. 1997). Within a positivist paradigm, policy decisions are often focused on the benefit of bureaucracies and those in power. The policy becomes a technology of control with political implications (Ball, 1994; Bourdieu \& Passeron, 1977; Foucault, 1980; Schmidt, 2008).

On the other hand, when viewed from a post modern policy perspective, issues can be investigated to illuminate the underlying motivation for the policy. This enables policy analysts to theoretically (re)interpret a particular policy environment and its contextual influences (Ball, 1994; Schmidt, 2008; Taylor et al. 1997). Post modern and post structural scholars (Ball, 1994; Foucault, 1980; Schmidt, 2008) argue that policy processes should be multi-dimensional in nature, as well as value-laden and contextual. Furthermore, policies are neither straightforward nor rational, and frequently result in unintended and even detrimental consequences (Schmidt, 2008). These characteristics challenge policy declarations that historically have striven to be value-neutral and free from contextual influences (Schmidt, 2008; Taylor et al., 1997). Critics stress that policy as discourse becomes a power struggle as to whose meaning is legitimated (Ball, 1994; 
Bourdieu 1977; Foucault, 1980; Schmidt, 2008). A post modern policy lens, then, acknowledges that policy development must consider context, placement, social location, and the purpose of implementation, as well as provide the potential to assist in solving long-term value-laden problems (Ball, 1994; Schmidt, 2008). Organizations cannot make significant changes overnight. It takes time, commitment, and an honest belief in the need to prioritize the experiences and histories of people who experience the greatest degrees of marginalization. Diverse voices and perspectives can help shape and drive organizational policies through a consensual process (Schmidt, 2008).

\section{Policy Problem}

As the driving force in society, education can either liberate or become a tool to reinforce stratification (Mannell, 2014). With a political ideology of democracy in South Africa, the hope is that education's curriculum reform (C2005, OBE), can lead the way in diminishing race, class, and gender inequalities. However, this has not been the case (Moorosi, 2007; Spreen \& Vally, 2006). Historically, the aftermath of apartheid damaged and continues to damage the socio-political fabric of the country. Twenty-three years after apartheid, unexpected consequences continue to impede not only social but also educational democracy. While sexism, racism, and classism were rife during apartheid, post-apartheid's dramatic shift toward transformation exacerbated these inequities. In fact, it is questioned if anything has changed from the days of apartheid schooling (Schmidt and Mestry, forthcoming).

\section{Historical Perspective of Education}

Before 1994, education was profoundly influenced by an apartheid ideology, which promoted segregated and inferior schooling primarily for black children. The school focused on basic skills and training for black children who were not expected to gain status in their adult years. In essence, black citizens had limited opportunities resulting in what Maile (2011) labels "black intellectual underdevelopment". Lack of quality education for blacks deepened the divide among "inferior" blacks and "superior" whites. Segregation and racial domination were the natural order of things (Maile, 2011).

After apartheid, the education of black children in post-apartheid South Africa remains ambiguous and begs the question: What new aims should be included in education, with particular reference to blacks in South Africa? This question can be applied and should be applied to curriculum policy today. Engelbrecht, Green, Naicker, \& Engelbrecht (1999) stress the importance of local control of curriculum and the knowledge that is shared with students in schools. They suggest that this is accomplished progressively. Local knowledge should not make up the entire content that children learn; however, local knowledge remains important to retain African culture. Scholars (e.g., Engelbrecht, Green, Naicker, \& Engelbrecht 1999) stress an integrated and inclusive curriculum that embraces diversity. 
Criticism of curriculum reform in South Africa reflects pessimism and disappointment as policies consist mainly of written documents that are not being implemented (Chisholm and Fuller, 1996; Jansen, 1998). In other words, curriculum policy remains in a permanent state of policy positioning and symbolism never meant to be implemented (Jansen, 1998). As in many other developing countries, curriculum reform in South Africa has left a legacy of structural and policy tensions. Some of these tensions include a lack of vision of the country's realities; symbolic policies placating mass expectations; poor school conditions inadequately implementing curriculum; and a lack of teacher knowledge to decipher outcomes-based learning (Rensburg, 2000). A focus therefore on what schools in society stand for and what they can realistically do and achieve, given their current socio-economic conditions is needed. In this regard, the National Qualifications Framework in South Africa encouraged local and community participation in schools through school governing bodies (SGBs). These school governing bodies are comprised of teachers, learners, parents and other relevant stakeholders at each school.

Since 1994, South Africa has had some curriculum reforms intended to address equality and social justices that were ill-addressed in the apartheid regime (Chisholm \& Fuller 1996; Jansen, 1998). A first step was the cleansing of syllabi from apartheid racist language and controversial and outdated content. Secondly, Curriculum 2005 and OBE (C2005) were launched. OBE was borrowed from countries such as Australia, New Zealand, Canada and parts of the United States of America that underpin social values such as peace, prosperity, non-sexism, non-racialism and democracy. Much work on implementation issues, however, was needed if the promises of the new curriculum are to make an impact in schools.

Problems with curriculum implementation began immediately with a shortage of textbooks and a lack of training for teachers. There was a sense of urgency by the new government to introduce a "new curriculum" that mirrored Western curricula with the introduction of outcomes-based learning and curriculum 2005. By 1997, 66 outcomes in eight disciplines as well as accompanying assessment standards had been developed. Assessment knowledge amongst educators was weak but it soon became apparent that assessment was the foundation of the success of these curricula changes. A paradigm shift needed to occur. In doing so, however, the rate and depth of curriculum changes were so swift that educators had difficulty keeping up. Curriculum 2005 meant that teachers needed to place more emphasis on formative assessment as a continuous feedback loop rather than on summative assessment that provides final test evaluations (Nakabugo \& Siebörger, 2001). Not surprisingly, research studies revealed that reliance of Curriculum 2005 on formative assessment as the foundation of curriculum changes made little progress. Nakabugo and Siebörger (2001) stress that establishing the outcomes and assessment standards and merely telling teachers they must change their approach to teaching was an unproductive approach. Without appropriate training, teachers were left to rely on their understanding and 
perceptions of curriculum documents, which we now know does not succeed (Schmidt \& Datnow, 2005).

\section{Outcomes-Based Education}

Various authors have traced the origins and nature of OBE. Fiske \& Ladd (2004) describe the method as an instructional one in which curriculum planners teach the general knowledge, skills, and values that learners should acquire. OBE is grounded in two pillars of knowledge: (1) competency-based education; and (2) mastery learning. Formative and summative assessments are rooted in OBE to ensure students meet the outcomes. In fact, the OBE model alleges that student success is solely the teacher's responsibility. If students have difficulty, remediation is available, and similarly, enhancement outcomes are available for those students who excel. Other forms of pedagogy used in OBE include authentic assessment, interdisciplinary teaching, and group learning (Darling-Hammond, Ancess, \& Falk, 1995).

The rhetoric of OBE is appealing. Who can disagree with a higher quality education for all students? Most would agree that schools need to improve and help students achieve more meaningful and life-enhancing outcomes. Many teachers' experiences with the implementation of OBE have produced debate and even doubts about OBE, despite the intent of providing teacher autonomy, increasing student self-esteem, improving attendance, and promoting high achievement of learner outcomes. These positive results may be valid in other countries, however, they are not so clear in South Africa. In South Africa, it seems there are more and perhaps different challenges than Western experiences and fewer benefits.

\section{Outcomes-Based Curriculum in South Africa}

In South Africa, OBE was not merely borrowed from Western countries and just handed down and accepted uncritically by South Africans. There are both local and global roots to OBE that had different impacts at different times. First, OBE can be traced within the labor movement that sought to overhaul the education system and incorporate an integrated approach to teaching (Cross, Mungadi, \& Rouhani, 2002). Spreen (2001) illustrates "how activists outside the traditional education establishment (with strong international ties) were instrumental in establishing the new educational agenda in South Africa" (p. 5). The emergence of outcomes-based education can be seen against the backdrop of globalization, and consequent converging tendencies within national education systems as educators increasingly learned from each other across borders (Steiner-Khamsi, 2014). In the minds of the main role players, though restricted to a small pool of countries in the Western world, OBE was regarded as "the state-of-the-art" thinking in Western schooling and the best international experience to address South African problems (Christie, 1999: p. 281). This view was met with criticism by those who saw OBE as an imposition of the Western world or, in other 
words, another manifestation of cultural imperialism. This is present for example in Kallaway et al. (1997) words when they suggests that:

In South Africa educational politics has increasingly been reduced to a matter of policy implementation. In the name of change and redress, and because of the need for politicians to produce demonstrable innovations in a short space of time, a range of policies, often hastily borrowed from foreign contexts without adequate research into their success and effects, have been bundled together with insufficient consultation or research (p. 1).

The quotation refers to the borrowing of an outcomes-based strategy without considering the contextual changes needed to make the policy effective. Postmodern policy analysis reminds us that education systems are part and parcel of the fabric of the societies in which they operate. For one to understand them, one must take into account their historical, political, social and cultural settings. Effective educational adoption requires a solid understanding of how ideas, concepts, and educational innovations are borrowed, adapted and implemented locally. Cultural imperatives are of paramount importance and the most important aspect to bear in mind when considering the possibilities of useful educational borrowing. It is the socio-cultural settings that keep policies in place and that provide resistance to the transfer of ideas from other countries and systems. The preparedness of local contexts to accept or receive such ideas is critical (Steiner-Khamsi, 2014: p. 3).

Jansen (1999) stresses that from a political perspective, the curriculum initiative was not meant to be implemented. He posits that the curriculum is part of state policy symbolism and political expediency to give the impression that change was taking place for disadvantaged groups. However, Jansen (1998) presents the caveat that it is not critically productive to simplify the problems with policy and to view global influences merely as impositions on local contexts since this would overlook the agency of local actors as well as the different forms that adaptation to local circumstances brings. Thus, although OBE reflects a pastiche of policy borrowing, in practice the issues are attempting to being woven into a texture of local concerns by the local population, which cannot be overlooked.

Another criticism of OBE is about the political process that should have informed the curriculum development. After labor's active involvement in initial curriculum debates, it is alleged, that the technocrats including foreign consultants, overpowered the discussion at the expense of local practitioners. The consequences were twofold. The role of teachers in curriculum design became marginal, and the curriculum was framed in obscure jargon. Curriculum 2005 has been criticized for using ambiguous language for teachers who are supposed to implement it, reducing the policy as an elitist system with profound political implications for the Government's redress project (Christie, 1999; Jansen, 1999b). Critics stress the lack of alignment between curriculum development, teacher development, selection and supply of learning materials (Potenza \& Ball, 1994). Thus the lack of co-ordination of curriculum led to poor implementation, ad hoc workshops 
(in place of teacher training), lack of relevant OBE materials, and delays as well as non-delivery of such materials. As Christie (1999) points out, the curriculum was poorly planned and hastily introduced in schools with teachers being insufficiently prepared with inadequate resources.

Another criticism is concerned with the degree of state interventionism in the curriculum process. For the critics, Curriculum 2005 represents an example of a bureaucratic-driven process of curriculum reform. Critical failings include too much alignment with socio-economic concerns at the expense of knowledge and pedagogical concerns; an inflexible (regulated) framework; the de-skilling of teachers; under-specification of content; and limited teacher participation in the conceptualisation and design of the curriculum (Rensburg, 2000). Rensburg (2000) argues that "for instruction to be effective the teacher must know more than the learner, must have adequate content knowledge, must know the conceptual destination of the learning, and therefore purposefully steer the learner towards a pre-set goal or outcome" (p. 9). With no content stipulations, the content and coverage are tacitly assumed to be in place. The consequence, as Rensburg (2000) puts it, is:

A success can be made of such an under-stipulated curriculum, but only if the teacher has a well-articulated mental script of what should be covered, and if the pupils come from homes where they have been well prepared to respond to such putative freedom, in other words, only in schools by and for the middle class. (p. 14)

\section{Policy Implications of Outcomes-Based Curriculum}

While, symbolically, outcomes-based curriculum brings South Africa to the world stage by offering a curriculum equal to that in Western countries, there are serious problems that need to be addressed internally. The most problematic issues regarding OBE include matters such as the borrowing and appropriation of the curriculum. Such action leads to significant consequences such as having no regard for the context within which the curriculum is being implemented; the impact on teachers and their lack of understanding and training of OBE; and the design and introduction (or not) into schools. Indeed, with curriculum change come tensions, particularly when the reform results in a significant paradigm shift or reconstruction of past curriculum. From a policy perspective, OBE and C2005 are grounded in such detail and technical and political skills that implementation for educational stakeholders remains challenging. As a political decision, Apple (1996) stresses that:

A curriculum is never simply a neutral assemblage of knowledge. Whether we like it or not, differential power intrudes into the very heart of a curriculum. What counts as knowledge, the ways in which it is organized, who is empowered to teach it, what counts as an appropriate display of having learned it, and who is allowed to ask and answer all these questions, are part and parcel of how dominance and subordination are reproduced and altered in South African society. Determining official knowledge is political, and 
often embodies conflict over what some may regard as neutral descriptions of the world, and may empower some groups while disempowering others.

(p. 66)

In contrast to the expectations stakeholders from government and civil society have on the new curriculum project, the policy soon became an object of controversy and contestation, culminating in a crisis within the school system. While some critics linked the crisis to the international roots of OBE, the Curriculum Review Committee, which was appointed by Government to address the crisis, placed the blame on the design and the implementation strategy (Cross, Mungadi, \& Rouhani, 2002).

OBE remains an experiment at different levels not only in South Africa but also in the Western countries still employing the curriculum in whole or in parts. For example, in Australia, OBE became part of a national mission with local adaptations. In Canada, OBE was a provincial experiment that gained popularity in Ontario. In Scotland, OBE was restricted to vocational programs within Glasgow. In the United States, OBE was met with much hostility at the state level but gained acceptance in the districts (Young, 2000). Apple (1996) presents the caveat that

Outcome-based education... is a simplistic solution to very complicated problems. The real issues involve the immense poverty in our inner cities and rural areas, the under financing of our schools, the lack of genuine respect for and cooperation with local minority communities, and the overly bureaucratic nature of our decision making (p. 78).

Critics stress that teachers subjected to a reform agenda in which they may have little ownership may feel insulted or brainwashed. In particular, the language of OBE is often labeled "elitist language," requiring translation from trainers. Not only is there a need to make the policy language clear, but there is a need to mobilize resources to under-funded and under-resourced schools; develop strategies and not just symbols for policy implementation; and move beyond policy from rhetoric to action (Dobson \& Koetting, 1985).

This analysis of OBE is not meant to ignore the benefits of OBE; however, the worry is whether these benefits apply within a South African context? For example, The Department of Education's role is to engage appropriate stakeholders, although often their voices are not heard in implementation meetings. Nevertheless, teachers need to be part of the process to be able to deliver the curriculum in their teaching. Problematization of OBE in South African schools is therefore required, regarding the range of expectations around an outcomesbased curriculum in South Africa (Jonathan, 2000).

A dimension of Curriculum 2005, which has been the object of much debate in South Africa, is the notion of adopting the curriculum from Western countries. Jonathan (2000) stresses the value of borrowing a system by understanding the importance of adapting the policy to the local environment and hopefully learning from past mistakes. 
That is to share our understanding from one society to another, not so much of what seems to work, given adequately favorable conditions, but of what has not worked anywhere. (p. 3)

Lehoko (2000), from the DOE, compared the use of outcomes-based pedagogy in Soweto and New Zealand. In doing so, he raises concern about the dangers of borrowing from a small system to apply to a vast and complex system such as South Africa. The biggest problem in this regard is undoubtedly the silence about experiences from other developing countries in the continent and elsewhere, even if it is to highlight what not to do (Cross, Mungadi, \& Rouhani, 2002).

\section{Conclusion}

Policy analysis of South African curriculum suggests that curriculum development and access do not necessarily mean equality. Patterns of privilege and disadvantage pervade the education system and beyond (see OECD, 2008). Where race and class have such detrimental consequences, we cannot claim that South African children have equal rights to education-in spite of near universal enrolment in schooling. Indeed, it could be argued that the right to education means the right to participate in an existing and enduring system of stratification (Christie, 2008: p. 9). What is needed is that the community, schools, parents, local education officials, and the media work together to mitigate limited access to schooling. This sort of synergistic participation by all stakeholders empowers communities to identify problems, develop plans for comprehensive and long-term solutions, and take action. There is a continued need for "conscientization" in society, the judiciary, and bureaucrats about the impact of poverty and continuing inequality despite democratic reforms (Kellner, 2000).

Policymakers, government, and other stakeholders seem to be always solving policy challenges theoretically, in the political sector, rather than, practically, in the classroom (e.g., OBE) (Chisholm \& Fuller, 1996; Jansen 2001). What is needed is a regard for implementation and training: “... the effectiveness of local schools will not magically increase if the policy agenda remains centered on symbols of opportunity" (Chisholm \& Fuller, 1996: p. 714). After policies are developed, it is expected that stages of implementation will be outlined for administrators. Implementation, however, is rarely found in South African education policy agendas (Spreen, 2006). Jansen (2000) chided the government for providing minimal training for Grade One teachers, regarding the implementation of OBE, which resulted in the hiring of untrained teachers. Teachers still question how to implement a new curriculum, with few resources, in large class sizes (Jansen, 2002). Most township schools in South Africa have still not even received access to any revised syllabi since the dissolution of the apartheid (Jansen, 1998).

Some scholars (e.g., Spreen \& Vally, 2006) believe educational goals are so out of context that they will never be reached. Collaborating with all stakeholders (even students) to work on plans for implementation proportions that foster 
goals aligned with those of the local communities in which the school children live remains critical. Education policy faces the dilemma of expressing and realizing the governing African National Congress's promises of equality without alienating those privileged opposition groups that possess the capital and expertise required to manage a modernizing state. In South Africa, the constitution (RSA 1996) incorporates the Bill of Rights, endorsing equality, human dignity, freedom, and security for all individuals along with other freedoms, social, and political rights. Decentralization of some powers to local levels could be ascribed as a means to prevent polarization (Lauglo, 1995: p. 8).

We see that South Africa is dedicated to being equal with the Western world on paper symbolically, but oppression still prevails (Spreen \& Vally, 2006). Many policies began symbolically with goals, aims, and mission statements. The future stages will hopefully include implementation and training for principals and teachers.

Effective reform should not be founded solely on economic concerns. Education policy based on research would focus on changing classroom practice, helping to validate curriculum and teaching models with extensive staff development, accepting the importance of local context, building strong relationships with families and communities, and building school capacity to improve. However, such improvement will not occur-indeed, cannot occur-until all stakeholders talk candidly and realistically about the policy. A policy that is based on rhetoric is destructive (Kauffman \& Konold, 2007). Education now falls under the routine scrutiny of the media and pervades the lives of the citizenry to an unprecedented degree. Consequently, the political stakes have increased in South Africa, along with the exposure of policy-makers to the potential of a major crisis in this policy sphere.

\section{References}

Apple, M. (1996). Cultural Politics and Education. Teachers College, Columbia University, NY.

Ball, S. J. (1994). What Is Policy? Texts, Trajectories and Toolboxes. In S. J. Ball (Ed.), Education Reform: A Critical and Post-Structural Approach (10-17). Buckingham: Oxford University Press.

Bourdieu, P., \& Passeron, J. (1977). Reproduction in Education, Society and Culture. Thousand Oak: Sage.

Chisholm, L., \& Fuller, B. (1996). Remember People's Education? Shifting Alliances, State-Building and South Africa's Narrowing Policy Agenda. Journal of Education Policy, 11, 693-716. https://doi.org/10.1080/0268093960110604

Christie, P. (1999). OBE and Unfolding Policy Trajectories: Lessons to Be Learned. In J. Jansen, \& P. Christie (Eds.), Changing the Curriculum: Studies on Outcomes-Based Education in South Africa (pp. 279-292). Cape Town: Juta.

Christie, P. (2008). Opening the Doors of Learning: Changing Schools in Post-Apartheid South Africa. Johannesburg: Heinemann.

Coombs, F. S., \& Lüschen, G. (1976). System Performance and Policymaking in West European Education: Effectiveness, Efficiency, Responsiveness, and Fidelity. International Review of Education, 22, 133-153. https://doi.org/10.1007/BF00598647 
Cross, M., Mungadi, R., \& Rouhani, S. (2002). From Policy to Practice: Curriculum Reform in South African Education. Comparative Education, 38, 171-187. https://doi.org/10.1080/03050060220140566

Darling-Hammond, L., Ancess, J., \& Falk, B. (1995). Authentic Assessment in Action. Columbia: Columbia University Press.

Dobson, R., \& Koetting, R. (1985). Looking at, Talking about, and Living with Children Reflections on the Process of Schooling. London: Institute of Philosophy.

Engelbrecht, P., Green, L., Naicker, S., \& Engelbrecht, L. (1999). Inclusive Education in Action in South Africa. Pretoria: J L van Schaik.

Fiske and Ladd (2004) Elusive Equity: Education Reform in Post-Apartheid South Africa. Washington DC: Brookings Institution Press.

Foucault, M. (1980). Power/Knowledge: Selected Interviews and Other Writings, 19721977. Trans. Colin Gordon et al. New York, NY: Pantheon.

Jansen, D. J. (2002). Political Symbolism as Policy Craft: Explaining Non-Reform in South African Education after Apartheid. Journal of Education Policy, 17, 199-215. https://doi.org/10.1080/02680930110116534

Jansen, D. J. 1998). Curriculum Reform in South Africa: A Critical Analysis of Outcomes-Based Education. Cambridge Journal of Education, 28, 321-331.

https://doi.org/10.1080/0305764980280305

Jonathan, R. (2000). The Role of Schooling in Social Transformation: High Hopes and Reasonable Expectations. Paper Presented at Kenton Ebhayi Conference, Port Elizabeth.

Kallaway, P., Kruss, G., Donn, G., \& Fataar, A. (1997). Introduction. In P. Kallaway, P. Kruss, G. Donn, \& Fataar, A. (Eds.), Education after Apartheid: South African Education in Transition (pp. 1-8). Cape Town: UCT Press.

Kauffman, J. M., \& Konold, T. (2007). Making Sense in Education: Pretense and Realities in Rhetoric and Policy about Schools and Schooling. Exceptionality, 15, 75-96. https://doi.org/10.1080/09362830701294151

Kellner, D. (2000). Globalization and New Social Movements: Lessons for Critical Theory and Pedagogy.

Lauglo, J. (1995). Forms of Decentralisation and Their Implications for Education. Comparative Education, 31, 5-29. https://doi.org/10.1080/03050069529182

Lehoko, K. (2000). Address to the HSRC, Pretoria, South Africa.

Maile, S. (2011). The Absence of a Home Curriculum in Post-Apartheid Education in South Africa. International Journal of African Renaissance Studies, 6, 100-117. https://doi.org/10.1080/18186874.2011.650852

Mannell, J. (2014). Conflicting Policy Narratives: Moving beyond Culture in Identifying Barriers to Gender Policy in South Africa. Critical Social Policy, 34, 454-474.

https://doi.org/10.1177/0261018314538794

Moorosi, P. (2007) Creating Linkages between Private and Public: Challenges Facing Women Principals in South Africa. South African Journal of Education, 27, 507-521.

Nakabugo, M. G., \& Siebörger, R. (2001). Curriculum Reform and Teaching in South Africa: Making a Paradigm Shift? International Journal of Educational Development, 21, 53-60.

Organization for Economic Co-Operation and Development (OECD) (2008). Reviews of National Policies for Education: South Africa. Paris: OECD.

Potenza, E., \& Ball, S. J. (1994). What Is Policy? Texts, Trajectories and Toolboxes. In S. J. Ball (Ed.), Education Reform: A Critical and Post-Structural Approach (pp. 10-17). 
Buckingham: Oxford University Press.

Rensburg, I. (2000). Reflections from the Inside: Key Policy Assumptions and How They Have Shaped Policy Making and Implementation in South Africa, 1994-2000. In A. Kraak, \& M. Young (Eds.), Education in Retrospect-Policy and Implementation since 1990. Pretoria: HSRC.

Schmidt, M., \& Datnow, A. (2005). Teachers' Sense-Making about Comprehensive School Reform: The Influence of Emotions. Teaching and Teacher Education, 21, 949-965.

Schmidt, M., \& Mestry, R. (forthcoming). Through the Looking Glass: An Intersectional Lens of South African Education Policy. In J. Jordan-Zachary, \& O. Hankivsky (Eds.), Bringing Intersectionality to Public Policy. Oxford: Oxford Press.

Schmidt, M. (2008). Risky Policy Processes: Accountability and School Leadership. In E. Samier (Ed.), Political Approaches to Educational Administration and Leadership (pp. 139-154). New York, NY: Routledge.

Spreen, C. (2001). Globalization and Education Policy Borrowing: Mapping out Outcomes-Based Education in South Africa. PhD Thesis, Teachers College, Columbia University.

Spreen, C. A., \& Vally, S. (2006). Education Rights, Education Policies and Inequality in South Africa. International Journal of Educational Development, 26, 352-362.

Steiner-Khamsi, G. (2014). Cross-National Policy Borrowing: Understanding Reception and Translation. Asia Pacific Journal of Education, 34, 153-167.

https://doi.org/10.1080/02188791.2013.875649

Taylor, S., Rizvi, F., Lingard, B., \& Henry, M. (1997). Education Policy and the Politics of Change. London: Routledge.

Young (2000). An International Perspective on Educational Reform. Pretoria: HSRC.

Zajda, J. (2002). Education and Policy: Changing Paradigms and Issues. International Review of Education, 48, 67-91. https://doi.org/10.1023/A:1015698126634

Submit or recommend next manuscript to SCIRP and we will provide best service for you:

Accepting pre-submission inquiries through Email, Facebook, LinkedIn, Twitter, etc. A wide selection of journals (inclusive of 9 subjects, more than 200 journals) Providing 24-hour high-quality service

User-friendly online submission system

Fair and swift peer-review system

Efficient typesetting and proofreading procedure

Display of the result of downloads and visits, as well as the number of cited articles Maximum dissemination of your research work

Submit your manuscript at: http://papersubmission.scirp.org/

Or contact ojps@scirp.org 